\title{
Wedge Biopsy of Liver
}

National Cancer Institute

\section{Source}

National Cancer Institute. Wedge Biopsy of Liver. NCI Thesaurus. Code C51918.

Removal of a wedge-shaped portion of theliver, for microscopic examination. 